\title{
The simultaneous removal of reactive and disperse dyes by Electrocoagulation Process with a bipolar connection of combined Iron and Aluminum electrodes: Experimental design and Kinetic studies
}

\author{
Noufissa Sqalli Houssini, Abdelhafid Essadki * and Esseddik EI Qars \\ Laboratory of Environment, Process, Energy (LEPE), Hassan II University, Ecole supérieure de Technologie, \\ BP.8012 Oasis, Casablanca, Morocco
}

\begin{abstract}
This study concerns the ability of electrocoagulation process to remove simultaneously disperse and reactive dyes by using combined iron and aluminum electrodes in bipolar mode. A statistical experiment design (Response Surface Methodology: RSM) was adopted to model the process and to optimize the parameters influencing the removal efficiency of the dyes. The mathematical model is established, using a rotatable central composite design uniform to study the empirical relationships between two responses (Removal efficiency, energy consumption) and five factors: initial $\mathrm{pH}$, current density, the concentration of supporting electrolyte, time and stirring speed. This treatment, therefore, led to a removal efficiency that can reach more than $95 \%$ with low consumption energy of $9 \mathrm{kWh} / \mathrm{Kg}$ of removed dye. Kinetic, isotherm adsorption and thermodynamic studies were undertaken with the optimized parameters. Electrocoagulation mechanism was modeled using adsorption kinetics and isotherm models, it is sited were on the insoluble iron and aluminum flocs. This study shows that the Freundlich model fit the adsorption isotherm, the kinetic of the electrocoagulation is better presented by the pseudo- second-order kinetic, the adsorption is endothermic and spontaneous for both dyes. Analysis of the sludge allowed quantifying the role of each electrode in removing dyes.
\end{abstract}

Keywords: Electrocoagulation; Bipolar mode connection; Mixed dyes; Kinetics; Thermodynamics.

\section{Introduction}

Textile industries use several chemicals for dying processes; the waters from this industry is loaded with toxic compounds that must be removed before being discharged.

Conventional methods for dealing with textile wastewater consist of various combinations of biological, physical and chemical methods ${ }^{1,2}$. biological treatment is limited because of the toxicity of some textile effluents ${ }^{3,4}$.

Techniques based on activated carbon adsorption, reverse osmosis and ultrafiltration are useful, however, they are expensive, and restricted for low concentration ranges ${ }^{5-6}$.

Coagulation-flocculation is one of the most used techniques for wastewater treatment ${ }^{7}$. Coagulation is achieved by the addition of iron salts or aluminum. The flocculation of the agglomerates is performed by the addition of organic polymers; however, this method produces a large number of flocs which requires a second treatment ${ }^{8}$. Electrochemical techniques hold a vital place.

*Corresponding author: Abdelhafid Essadki

Email address: essadkiha@gmail.com

DOI: http://dx.doi.org/10.13171/mjc10202002191222ae
The electrocoagulation technique is one of the most effective and promising methods applied for treatment of different pollutants (such as emulsified oils, heavy metals, dyes, and other organic pollutants) in domestic and industrial wastewater effluents, it is based on the electrochemical dissolution of the anode that leads to the formation of metallic cations which form complexes with the hydroxide ions ${ }^{9}$, the dominant species is $\mathrm{pH}$-dependent. These complexes act as coagulants, adsorb particles and thus cancel the colloidal fillers.

The main reactions taking place with the iron electrodes are ${ }^{10}$.

Anode: $\mathrm{Fe} \rightarrow \mathrm{Fe}^{2+}+2 \mathrm{e}^{-}$

Cathode: $2 \mathrm{H}_{2} \mathrm{O}+2 \mathrm{e}^{-} \rightarrow 2 \mathrm{OH}^{-}+\mathrm{H}_{2}(\mathrm{~g})$

Overall reaction:

$\mathrm{Fe}^{2+}+2 \mathrm{OH}^{-} \rightarrow \mathrm{Fe}(\mathrm{OH})_{2}(\mathrm{~s})$ (greenish color)

$\mathrm{Fe}(\mathrm{OH})_{2}$ is then oxidized to form $\mathrm{Fe}(\mathrm{OH})_{3}{ }^{11-12}$.

In the case of aluminum electrodes, the reactions taking place at the electrodes are as follow: The oxidation takes place at the anode:

Received December 9, 2019

Accepted January 13, 2020

Published February 19, 2020 


$$
\mathrm{Al} \rightarrow \mathrm{Al}^{3+}+3 \mathrm{e}^{-}
$$

For higher current density:

$$
4 \mathrm{OH}^{-} \rightarrow \mathbf{2} \mathrm{H}_{2} \mathrm{O}+\mathrm{O}_{2}+2 \mathrm{e}
$$

The reduction takes place at the cathode:

$$
2 \mathrm{H}_{2} \mathrm{O}+2 \mathrm{e}^{-} \rightarrow 2 \mathrm{H}_{2}+2 \mathrm{OH}^{-}
$$

The intense colour is one of the most challenging parameters to eliminate, which explains a large number of works that have been reported about it ${ }^{13-14}$.

In a previous work ${ }^{10}$, Bella et al. (2010) have proved that iron anodes were more adequate for reactive and mixture (disperse + reactively) dyes, whereas the aluminum electrodes were more efficient to disperse dyes removal. In a previous article ${ }^{15}$, the efficiency of electrocoagulation/electroflotation in removing colour from real textile wastewater by using aluminum and iron electrodes have been studied in a pilot external-loop airlift reactor. Other studies have also proved that $\mathrm{Al}$ electrodes were more effective than Fe electrodes in TOC removal ${ }^{16}$.

Bipolar mode of electrodes has been used to treat laundry wastewater by electrocoagulationelectroflotation ${ }^{17}$, but sacrificial anodes were only made by aluminum.

The purpose of this paper is to apply this technique in order to treat disperse red and reactive blue dyes as synthetic effluent textile from a textile industry based in Casablanca.

First, the statistical experimental design JMP (John's Macintosh Project), it is a suite of computer programs for statistical analysis used in applications such as Six Sigma, engineering, design of experiments, as well as for research in science, engineering... JMP is adopted to determine the optimal parameters such as $\mathrm{pH}$, conductivity, current density, electrolysis time, and stirring speed to minimize consumption energy and anode consumption for better removal efficiency. Then, the kinetics of electrocoagulation and analysis of the flocs and the treated solution is studied in order to comprehend the role of each type of electrodes to remove simultaneously disperse and reactive dyes.

The use of combined aluminum and iron electrodes for the removal of a mixture of dyes has not yet been investigated by other authors. The goal is to quantify the effect of each anode for a bipolar connection mode (Fe -Al-Al-Fe).

\section{Materials and Methods}

The dyes used as synthetic effluent textile are disperse red dyes 74 whose wavelength is $569 \mathrm{~nm}$ and the reactive blue whose wavelength is $600 \mathrm{~nm}$ as illustrated in Figure 1 and 2. They were mixed with the same concentration, after that, sodium hydroxide was added to adjust conductivity, and two solutions of hydrochloric acid and sodium hydroxide $(0,5 \mathrm{M})$ were prepared to adjust $\mathrm{pH}$ of the solution. Electrocoagulation experiments were carried out in a stirred glass tank. A propeller stirrer of length $(\mathrm{h}=6 \mathrm{~cm})$ was placed in the middle of the compartment at $4 \mathrm{~cm}$ from the bottom of the reactor to avoid flocs decantation and promote electrocoagulation. The reactor volume was 5 liters. The solution was stirred at $100 \mathrm{rpm}$ with a mechanical stirrer to ensure better homogenization of the mixture. The temperature of the solution has been monitored to the desired value with a digital thermostat as a thermostatic bath (Ultratemp 2000). A photo of the electrocoagulation cell is illustrated in Figure 3. As illustrated in Figure 4, four electrodes were used in bipolar connection; the area of each electrode (Fe and Al) is $70 \mathrm{~cm}^{2}$. The electrodes have been previously treated with an abrasive paper at their surface, in order to homogenize them and remove impurities and deposits which can contaminate them, two iron electrodes are connected to the generator, and two aluminum electrodes were placed between iron electrodes without any connection, they are fixed on a wooden support with an inter-electrode distance of $1 \mathrm{~cm}$ then immersed in the effluents.

This arrangement ensures, on the one hand, a large area and on the other hand, leads to the use of aluminum and iron as sacrificial anodes. With bipolar electrodes, the cells are in series. The sacrificial electrodes are placed between the two parallel electrodes without any electrical connection. Only the two monopolar electrodes are connected to the electric power source with no interconnections between the sacrificial electrodes ${ }^{18}$. The iron electrodes were connected to a power generator (DC power supply) (BK precision).

After treatment the electrodes are cleaned by immersion in a hydrochloric acid solution $(0.1 \mathrm{M})$ for 30 minutes then rinsed and dried at room temperature for 1 hour to be measured by a very accurate balance 'Precisa 205 A'.

The color evolution was monitored by absorbance measurement using a UV-visible spectrophotometer (HEגIOS) with two wavelengths of $569 \mathrm{~nm}$ and $600 \mathrm{~nm}$ corresponding to the maximum absorbance of respectively disperse and reactive dyes. Samples containing the same concentrations for both types of dyes were prepared. Absorbance for different concentrations was measured for both wavelengths to study the evolution of each type of dye. A linear evolution between concentration and absorbance was obtained.

A pH-meter (CRISON pH-meter BASIC 20+), and a conductivity-meter (CRISON EC-meter BASIC 30+) were used to measure respectively $\mathrm{pH}$ and conductivity. $\mathrm{pH}$ was adjusted by adding hydrogen chloride $(\mathrm{HCl})$ or hydroxide sodium $(\mathrm{NaOH})$.

The percentage of color removal was calculated by using (equation 7) ${ }^{19}$ : 


$$
Y \%=\frac{A b s_{0}-A b s_{i}}{A b s_{0}} \times 100
$$

Where $\mathrm{Abs}_{0}$ and $\mathrm{Abs}_{\mathrm{i}}$ are respectively the initial absorbances and the absorbance at a specific time.

The specific electrical energy consumption per $\mathrm{kg}$ of dye removed was calculated as follows:

$E=\frac{U \times I \times t}{V \times C_{0} \times Y \%} \mathrm{KWh} / \mathrm{Kg}$ of removed dyes<smiles>CC(=O)Nc1cc(NCC(C)O)c(Cl)cc1N=Nc1ccc([N+](=O)[O-])cc1Cl</smiles>

Figure 1. Molecular structure of disperse Red 74 $(569 \mathrm{~nm})$

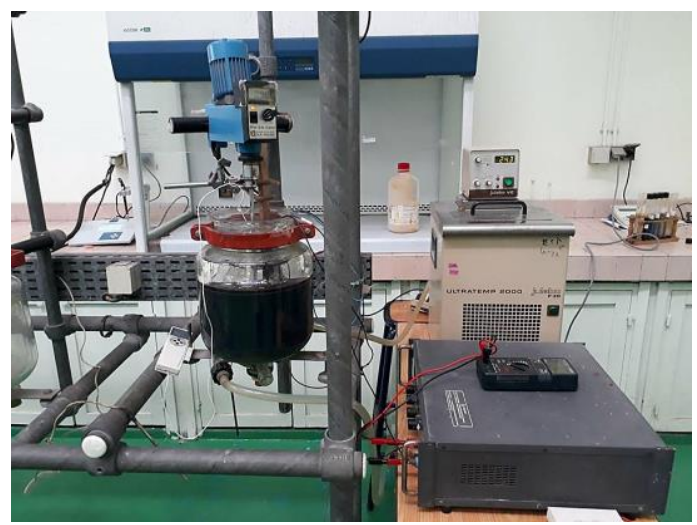

Figure 3. Experimental setup

\subsection{Statistical analysis}

Optimization of the removal of reactive and disperse dyes by electrocoagulation is achieved by using the RSM (11.2.1 version), RSM is a practical tool for the design of experiments., it is useful for modeling and analysis of problems ${ }^{20} \mathrm{~A}$ rotatable central composite where: U (V) cell voltage; I (A) current intensity; t (h) electrolysis time; $\mathrm{V}(\mathrm{L})$ liquid volume, $\mathrm{C}_{0}(\mathrm{~kg} / \mathrm{l})$ initial dye concentration and $\mathrm{Y}$ dye removal efficiency.

The difference of mass of the anode is calculated by the following formula:

$\% F e(A l)=\frac{\left(m_{0}-m_{f}\right)}{m_{0}} \times 100$

Where $\mathrm{m}_{0}$ is the initial mass of the anode, $\mathrm{m}_{\mathrm{f}}$ is the final mass after electrocoagulation. The mass of the cathode was also measured before and after electrocoagulation.

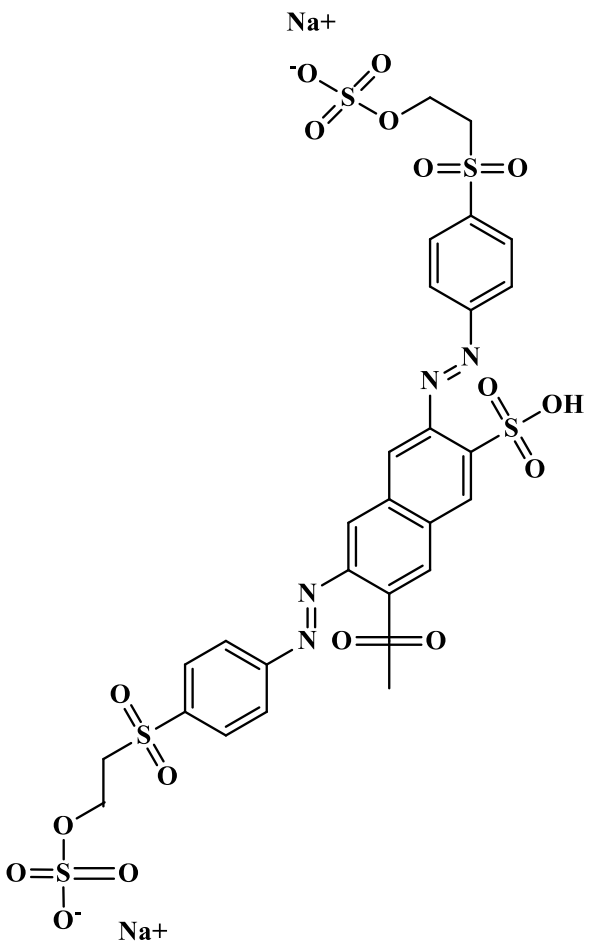

Figure 2. Molecular structure of reactive Blue $(600 \mathrm{~nm})$

\section{Generator DC}

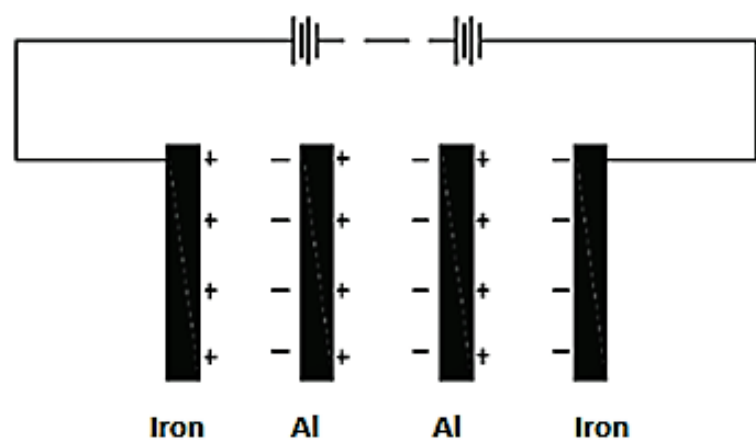

Figure 4. Bipolar connection mode of iron/aluminum electrodes

design uniform is used to study the empirical relationships between two responses (removal efficiency, energy consumption) and five factors: initial $\mathrm{pH}$, current density, electrolysis concentration, time and stirring speed ${ }^{21}$. 


\subsection{Mathematical model}

The factorial experimental designs use the following mathematical model that links the response $y$ to

$$
Y=a_{0}+a_{1} \times x_{1}+a_{2} \times x_{2}+\ldots a_{n} \times x_{n}+\sum_{i, j=1 i \neq j}^{n} a_{i j} \times x_{i} \times x_{j}+\sum_{i, j, k=1 i \neq j \neq k}^{n} a_{i j k} \times x_{i} \times x_{j} \times x_{k}+\ldots
$$

Where:

$\mathrm{y}$ : theoretical response function;

$\mathrm{Xj}$ : coded variables of the system;

$a_{0}$, aij, $a_{i j k}$ : true model coefficients.

\subsection{Experimental field}

To study the combined effect of five factors, experiments are performed for different combinations of the physical parameters using statistically designed experiments. Each parameter has two levels: -1 or +1 indicating respectively minimum and maximum.

The variables are coded according to the following equation: factors $\mathrm{X}_{1}, \mathrm{X}_{2}, \ldots \mathrm{X}_{\mathrm{i}} \ldots \ldots \mathrm{X}_{\mathrm{n}}$. This is a polynomial model $^{22}$.
$X_{i}=\frac{x_{i}-x_{0}}{\Delta x}$

$\mathrm{X}_{\mathrm{i}}$ : the dimensionless value of an independent variable .

$\mathrm{x}_{\mathrm{i}}$ : the real value of an independent variable.

$\mathrm{x}_{0}$ : the value of $\mathrm{x}_{\mathrm{i}}$ at the center point.

$\Delta \mathrm{x}:$ is the step range.

The corresponding five variable central composite designs are shown in Table 1. Twelve experiments are used to estimate the model coefficients.

Table 1. Experimental design matrix using central composite design.

\begin{tabular}{|c|c|c|c|c|c|c|c|c|c|c|}
\hline \multirow[b]{2}{*}{ Run } & \multicolumn{5}{|c|}{ Coded values } & \multicolumn{5}{|c|}{ Real values } \\
\hline & $\mathbf{X 1}$ & $\mathbf{X} 2$ & $\mathbf{X 3}$ & $\mathbf{X} 4$ & $\mathbf{X 5}$ & $\begin{array}{c}\text { Current } \\
\text { density } \\
\left(\mathbf{m A} / \mathbf{c m}^{2}\right)\end{array}$ & Initial pH & $\begin{array}{c}\text { Processing } \\
\text { time } \\
(\text { min })\end{array}$ & $\begin{array}{c}\text { Concentration } \\
\text { of supporting } \\
\text { electrolyte } \\
(\mathrm{mg} / \mathrm{l})\end{array}$ & $\begin{array}{l}\text { Stirring } \\
\text { speed } \\
\text { (rpm) }\end{array}$ \\
\hline 1 & -1 & -1 & -1 & -1 & -1 & 5 & 4 & 20 & 1 & 50 \\
\hline 2 & 1 & 1 & -1 & -1 & 1 & 25 & 11 & 20 & 1 & 200 \\
\hline 3 & -1 & 1 & 1 & -1 & 1 & 5 & 11 & 60 & 1 & 200 \\
\hline 4 & 1 & -1 & -1 & 1 & -1 & 25 & 4 & 20 & 5 & 50 \\
\hline 5 & -1 & 1 & 1 & 1 & -1 & 5 & 11 & 60 & 5 & 50 \\
\hline 6 & 1 & 1 & -1 & -1 & -1 & 25 & 11 & 20 & 1 & 50 \\
\hline 7 & -1 & -1 & 1 & -1 & -1 & 5 & 4 & 60 & 1 & 50 \\
\hline 8 & 1 & 1 & 1 & 1 & -1 & 25 & 11 & 60 & 5 & 50 \\
\hline 9 & -1 & -1 & -1 & 1 & 1 & 5 & 4 & 20 & 5 & 200 \\
\hline 10 & 1 & -1 & 1 & 1 & 1 & 25 & 4 & 60 & 5 & 200 \\
\hline 11 & -1 & 1 & -1 & 1 & 1 & 5 & 11 & 20 & 5 & 200 \\
\hline 12 & 1 & -1 & 1 & -1 & 1 & 25 & 4 & 60 & 1 & 200 \\
\hline
\end{tabular}

By default the software offers a Randomize random order, the 12 experiments are carried out to determine the answers, the table below shows both the five factors and the two responses at each case (Table 2).

Table 2. Data matrix of factors and responses.

\begin{tabular}{|c|c|c|c|c|c|c|c|}
\hline Order & $\begin{array}{c}\text { Current } \\
\text { density } \\
\left(\mathbf{m A} / \mathbf{c m}^{\mathbf{2}}\right)\end{array}$ & $\begin{array}{c}\text { Initial } \\
\mathbf{p H}\end{array}$ & $\begin{array}{c}\text { Concetration of } \\
\text { supporting } \\
\text { electrolyte } \mathbf{( g / \mathbf { l } )}\end{array}$ & $\begin{array}{c}\text { Stirring } \\
\text { speed } \\
\mathbf{( r p m )}\end{array}$ & $\begin{array}{c}\text { Processin } \\
\text { time (min) }\end{array}$ & $\begin{array}{c}\text { Removal } \\
\text { efficiency } \\
\mathbf{( \% )}\end{array}$ & $\begin{array}{c}\text { Consumption energy } \\
\mathbf{( K g / K W h ~ o f ~ d y e s ) ~}\end{array}$ \\
\hline 1 & 5 & 4 & 5 & 200 & 60 & 71.77 & 1.789 \\
\hline 2 & 25 & 11 & 1 & 200 & 20 & 93.94 & 14.903 \\
\hline 3 & 5 & 11 & 5 & 200 & 60 & 92.72 & 1.200 \\
\hline
\end{tabular}




\begin{tabular}{|c|c|c|c|c|c|c|c|}
\hline 5 & 25 & 4 & 5 & 50 & 20 & 91.19 & 6.320 \\
\hline 6 & 25 & 4 & 5 & 200 & 20 & 89.96 & 6.530 \\
\hline 7 & 5 & 4 & 1 & 50 & 60 & 37.85 & 1.875 \\
\hline 8 & 5 & 4 & 1 & 50 & 20 & 72.24 & 3.214 \\
\hline 9 & 5 & 11 & 1 & 200 & 60 & 81.49 & 0.965 \\
\hline 10 & 25 & 11 & 5 & 50 & 60 & 97.61 & 17.626 \\
\hline 11 & 25 & 4 & 1 & 200 & 60 & 92.47 & 41.526 \\
\hline 12 & 25 & 11 & 1 & 50 & 60 & 96.95 & 40.845 \\
\hline
\end{tabular}

\subsection{Validation of the model}

John's Macintosh Project software is performed for regression and graphical analysis of obtained data. The optimum of studied parameters $(\mathrm{pH}$, current density, electrolysis concentration, time, and stirring speed) is obtained by analyzing the response surface contour plots. The validation of the model is considered adequate if the variance due to regression is different from the total variance (ANOVA).

\section{Results and discussions}

\subsection{Optimization of electrocoagulation process} parameters by experimental design

Optimization of the removal dyes by electrocoagulation is achieved by using the JMP (John's Macintosh Project) software which offers various functionalities for the analysis and experimental design. It is used to study the empirical relationships between two responses (Removal efficiency of dyes " $y_{1}$ " and consumption energy " $y_{2}$ ") and five factors: current density, $\mathrm{pH}$, processing time, the concentration of supporting electrolyte and stirring speed.

The model is then analyzed, the coefficients have been sorted according to their impact on the response, those that cross the blue line have a huge impact, but the others cannot be neglected.

The most critical parameters, which affect the efficiency of electrocoagulation, are current density, $\mathrm{pH}$ and processing time, as shown in Figure 5 and 6.

\section{Factors}

Current density $(\mathrm{mA} / \mathrm{cm} 2)(5,25)$

Initial $\mathrm{pH}(4,11)$

Processing time $(\mathrm{min})(20,60)$

Stirring speed $(\mathrm{rpm})(50,200)$

Concentration of supporting electrolyte $(g / l)(1,5)$

$\begin{array}{rrr}\text { Estimate } & \text { Standard } \\ 11,145 & 2,766043 & 4,03 \\ 6,6283333 & 2,766043 & 2,40 \\ 4,7516667 & 2,766043 & 1,72 \\ 4,5166667 & 2,766043 & 1,63 \\ 3,385 & 2,766043 & 1,22\end{array}$

Prob. $>|t|$

$0,0069^{*}$

0,0536

0,1366

0,1536

0,2669

Figure 5. Sorted Parameter Estimates (\% removal efficiency)

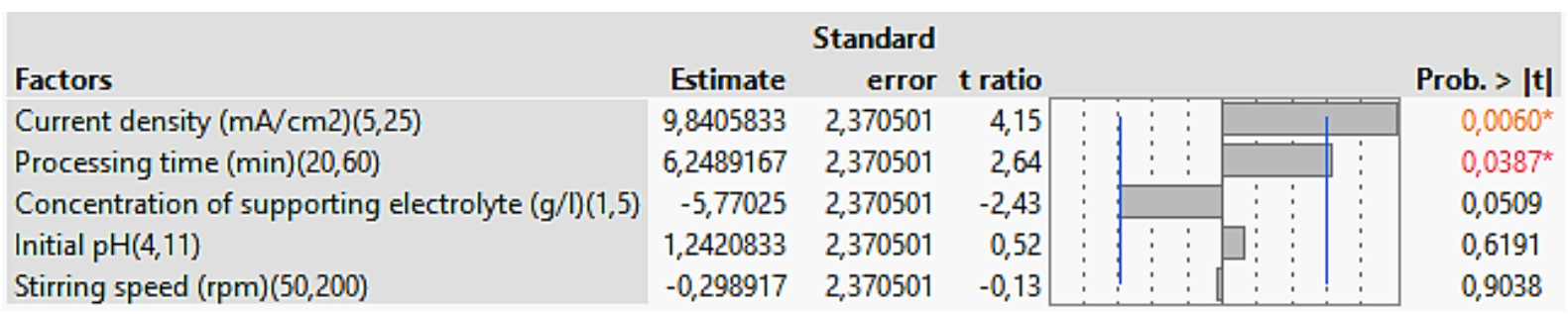

Figure 6. Sorted Parameter Estimates (\% consumption energy)

Before talking about optimization, it would be interesting to have more information about some elements, the factors that have an impact are now defined linearly but it could be interesting to see if there will be other second-order terms that appear in our model.
The experiments were carried out by setting the stirring speed at $100 \mathrm{rpm}$, and the electrolyte concentration at 2.5g/l (Optimal for maximum elimination percentage and minimum energy consumption) the term block is automatically assigned by the software, Table 3 summarize the news experiences for enhanced experimental design. 
Table 3. Data matrix of factors and responses of enhanced experimental design.

\begin{tabular}{|c|c|c|c|c|c|c|}
\hline Order & $\begin{array}{c}\text { Current density } \\
\left(\mathbf{m A} / \mathbf{c m}^{\mathbf{2}}\right)\end{array}$ & Initial pH & $\begin{array}{c}\text { Processing time } \\
(\mathbf{m i n})\end{array}$ & $\begin{array}{c}\text { Bloc } \\
\mathbf{1}\end{array}$ & $\begin{array}{c}\text { Removal efficiency } \\
(\boldsymbol{\%})\end{array}$ & $\begin{array}{c}\text { Consumption energy } \\
(\mathbf{K g} / \mathbf{K W h} \text { of dyes })\end{array}$ \\
\hline 13 & 5 & 4 & 20 & 2 & 60.1 & 5.524 \\
\hline 14 & 15 & 7.5 & 40 & 2 & 94.8 & 7.322 \\
\hline 15 & 25 & 7.5 & 40 & 2 & 95.8 & 18.799 \\
\hline 16 & 5 & 11 & 60 & 2 & 94.0 & 1.602 \\
\hline 17 & 15 & 7.5 & 60 & 2 & 97.5 & 11.529 \\
\hline 18 & 25 & 11 & 20 & 2 & 96.4 & 9.590 \\
\hline 19 & 15 & 4 & 40 & 2 & 85.41 & 7.950 \\
\hline 20 & 25 & 4 & 60 & 2 & 91.75 & 28.054 \\
\hline
\end{tabular}

The mathematical model of the removal efficiency is expressed by the following quadratic equation:

$$
Y_{1}=100.65+13.64 X_{1}-10.46 X_{2}+8.55 X_{3}-14.43 X_{1}^{2}-8.06 X_{1} X_{2}+0.7 X_{2}^{2}-7.6 X_{1} X_{3}-3.87 X_{2} X_{3}-7.63 X_{3}^{2}
$$

The energy consumption is also expressed by the quadratic equation:

$$
Y_{2}=6.71+9.26 X_{1}-0.44 X_{2}+5.57 X_{3}-3.38 X_{1}^{2}-0.53 X_{1} X_{2}+1.35 X_{2}^{2}+5.74 X_{1} X_{3}-1.19 X_{2} X_{3}-0.19 X_{3}^{2}
$$

Table 4 and 5 shown Regression variance analysis for the two responses; the significant value of $\mathrm{F}$ indicates that the most of the variation in the response can be explained by the regression equation. The associated $\mathrm{P}$-value is used to estimate whether F-statistics is large enough to indicate statistical significance. A P value lower than 0.01 indicates that the model is considered to be statistically significant, this also means that at least one of the terms in the regression equation has a significant correlation with the response variable.

The ANOVA of removal efficiency and consumption energy indicates that the second-order polynomial model (equations 6 and 7) is highly significant and adequate to represent the actual relationship between the responses and variables, with small $\mathrm{P}$ values $(\mathrm{P}<0.001)$ and a high value of regression coefficient.

Table 4. Regression variance analysis for dyes removal efficiency.

\begin{tabular}{|c|c|c|c|c|c|}
\hline Source & $\begin{array}{c}\text { Degree of } \\
\text { freedom }\end{array}$ & $\begin{array}{c}\text { Sum of } \\
\text { squares }\end{array}$ & Mean square & F statistics & P \\
\hline Model & 10 & 9010.6059 & 901.061 & & $<0.0001$ \\
\hline Residual & 9 & 423.7497 & 47.083 & 19.1376 & \\
\hline Total & 19 & 9434.3556 & & & \\
\hline
\end{tabular}

Table 5. Regression variance analysis for consumption energy.

\begin{tabular}{|c|c|c|c|c|c|}
\hline Source & $\begin{array}{c}\text { Degree of } \\
\text { freedom }\end{array}$ & $\begin{array}{c}\text { Sum of } \\
\text { squares }\end{array}$ & Mean square & F statistics & P \\
\hline Model & 10 & 2522.1988 & 252.220 & & $<0.001$ \\
\hline Residual & 9 & 426.6397 & 47.404 & 5.3206 & \\
\hline Total & 19 & 2948.8385 & & & \\
\hline
\end{tabular}

Contour plots for dyes removal efficiency and consumption energy in Figure 7 and 8 show the interaction effect of current density and initial $\mathrm{pH}$ at fixed values of the processing time (60min), the current density and $\mathrm{pH}$ increase simultaneously. Then, to have weak energy, it is beneficial to work with low current density, the lowest value of the current density, which gives a maximum of dyes removal is $12 \mathrm{~mA} / \mathrm{cm}^{2}$. 


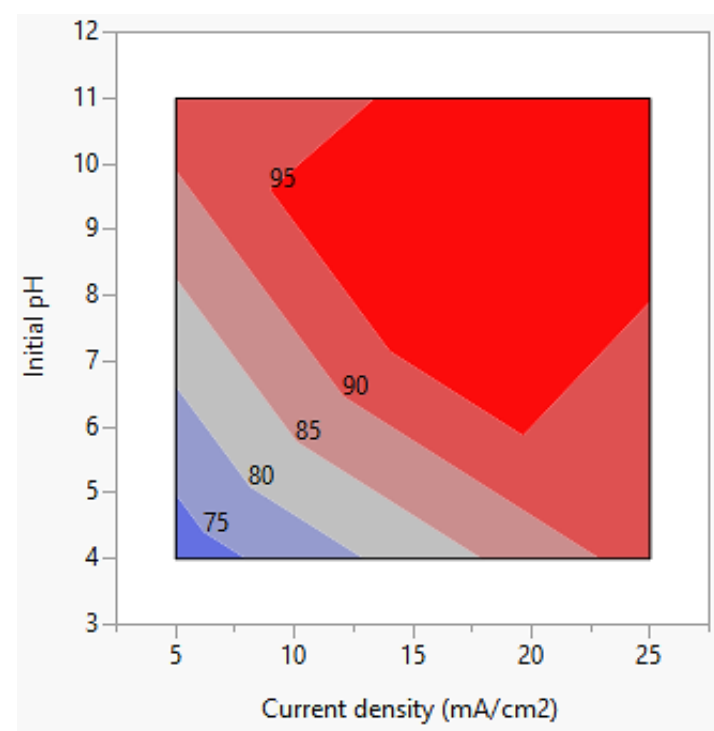

Figure 7. Isoresponse contour plot for removal efficiency $($ time $=60)$

The responses surface plots as illustrated in Figure 9, and 10 represents also combined influence of current density and initial $\mathrm{pH}$ at fixed values of the processing time (60min), as shown responses has been affected

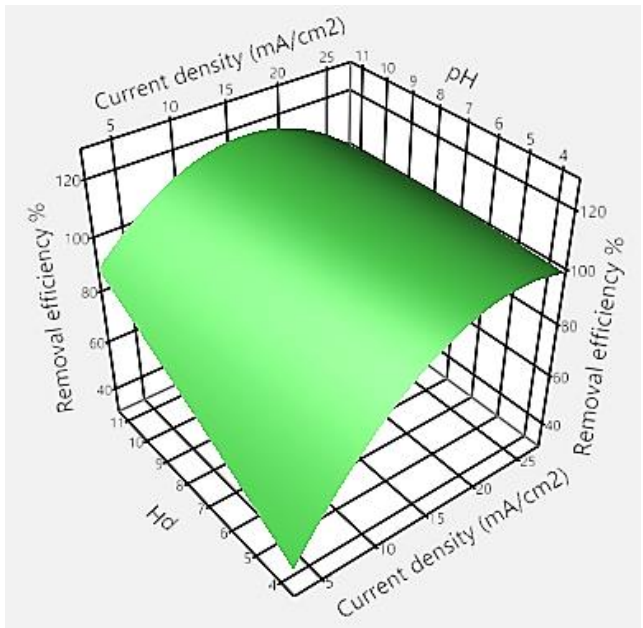

Figure 9. Response surface plots showing the effect of current density and initial $\mathrm{pH}$ on removal efficiency of dyes at fixed time

From where the optimum condition for removal dyes from the textile industry is given in Table 6 Under these conditions, the estimated values of dyes removal

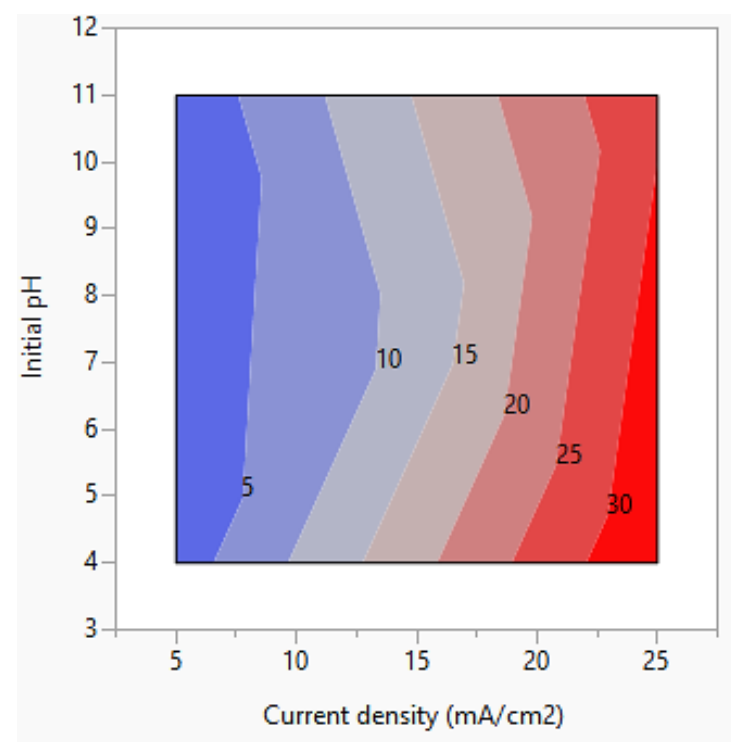

Figure 8. Isoresponse contour plot for consumption energy (time $=60)$

by factors, current density is about $15 \mathrm{~mA} / \mathrm{cm} 2$ and the $\mathrm{pH}$ points towards the acid zone, leads to a higher removal efficiency $>95 \%$ and higher values of $\mathrm{pH}$ and current density leads to a higher consumption energy.

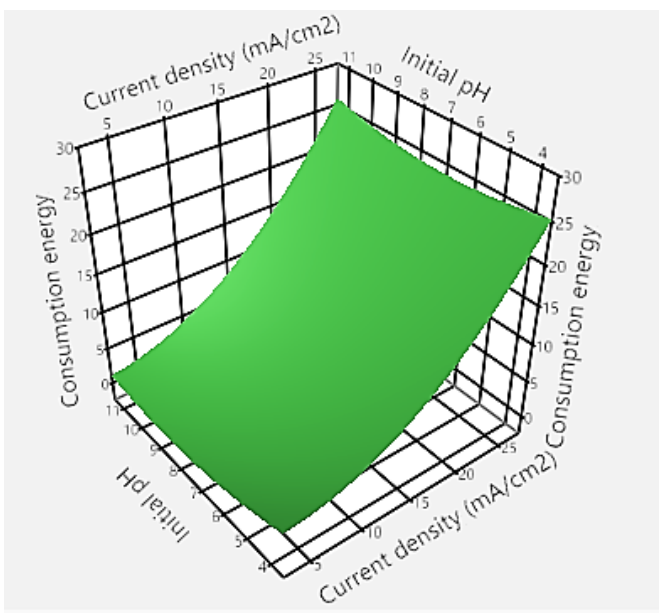

Figure 10. Response surface plots showing the effect of current density and initial $\mathrm{pH}$ on consumption energy at fixed time

efficiency, energy consumption for the treatment by electrocoagulation process are respectively, 96,5\% and $9.13 \mathrm{kWh} / \mathrm{kg}$ of removed dye. This result is experimentally confirmed.

Table 6. Optimum values of the process parameters.

\begin{tabular}{|c|c|}
\hline Parameters & Values \\
\hline Current density & $12.37 \mathrm{~mA} / \mathrm{cm}^{2}$ \\
\hline $\mathrm{pH}$ & 5.9 \\
\hline Electrolysis concentration & $2 \mathrm{~g} / \mathrm{l}$ \\
\hline Processing time & $60 \mathrm{~min}$ \\
\hline Stirring speed & $100 \mathrm{rpm}$ \\
\hline
\end{tabular}




\subsection{Kinetic study}

During electrocoagulation, the dyes are adsorbed at the surface of metal hydroxides continuously.

To study the adsorption kinetics of the two dyes (dispersed red and reactive blue) on the floc containing metal hydroxides $(\mathrm{Fe}(\mathrm{OH}) 3$ and $\mathrm{Al}(\mathrm{OH}) 3)$, the optimal conditions are $\mathrm{pH}=5.9$, $\mathrm{j}=12.37 \mathrm{~mA} / \mathrm{cm} 2, \mathrm{C}=2.5 \mathrm{mS} / \mathrm{cm}$ ) and $25^{\circ} \mathrm{C}$ as the working temperature was used. The influence of temperature is then analyzed to determine the activation energy.

The amount of dye removed at time $t, Q_{t}\left(\mathrm{mg} \cdot \mathrm{g}^{-1}\right)$, was calculated using (equation 14) ${ }^{23}$ and represented in Figures 11 and 12:

$$
Q_{t}=\frac{\left(C_{0}-C_{t}\right) \times V}{m}
$$

Where:

$\mathrm{Q}_{\mathrm{t}}$ : the amount of dyes adsorbed on the adsorbent at time $\mathrm{t}(\mathrm{mg} / \mathrm{g})$.

$\mathrm{C}_{0}$ : the initial concentration of the solution to be treated $(\mathrm{mg} / \mathrm{l})$;

$\mathrm{C}_{\mathrm{t}}$ : the concentration of the dye at time $\mathrm{t}(\mathrm{mg} / \mathrm{l})$;

$\mathrm{V}$ : the volume of the solution (liter);

$\mathrm{m}$ : Loss mass of electrodes (iron and aluminum).

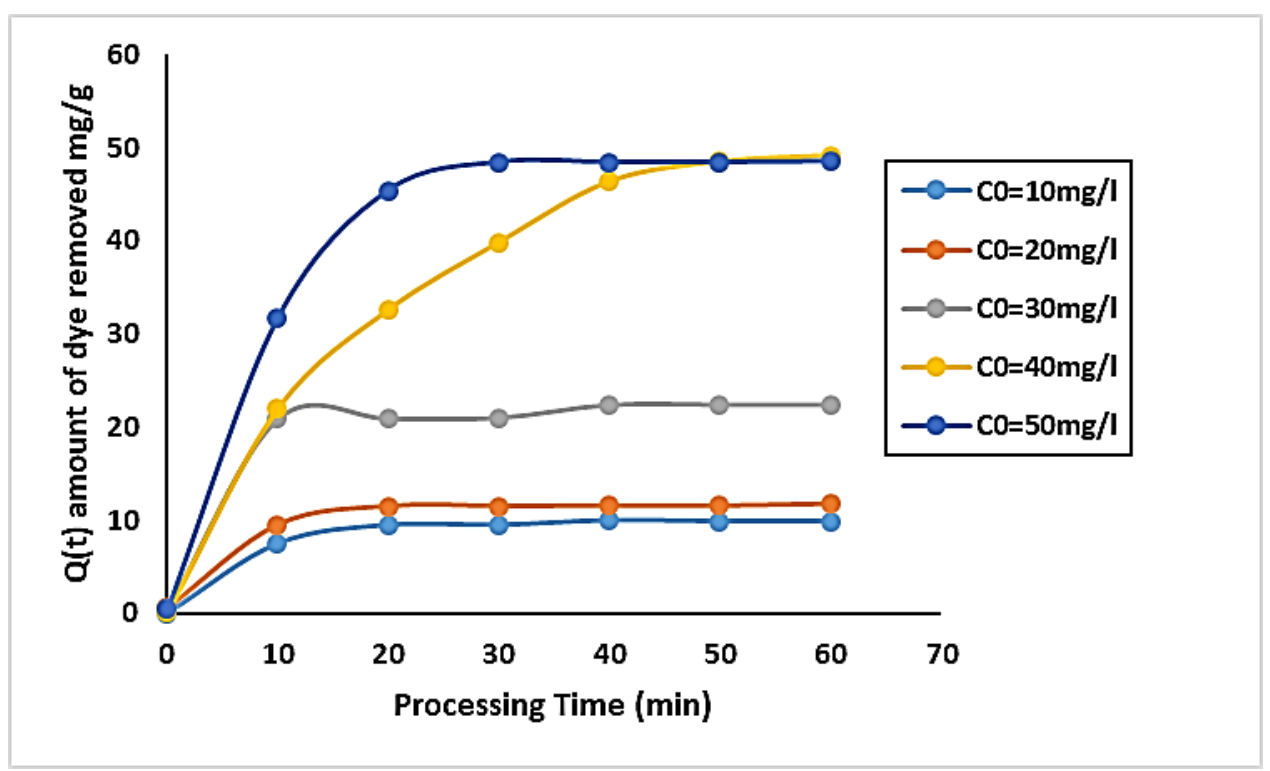

Figure 11. Effect of electrolysis time and initial concentration on the amount of disperse red dye adsorbed (Optimal conditions)

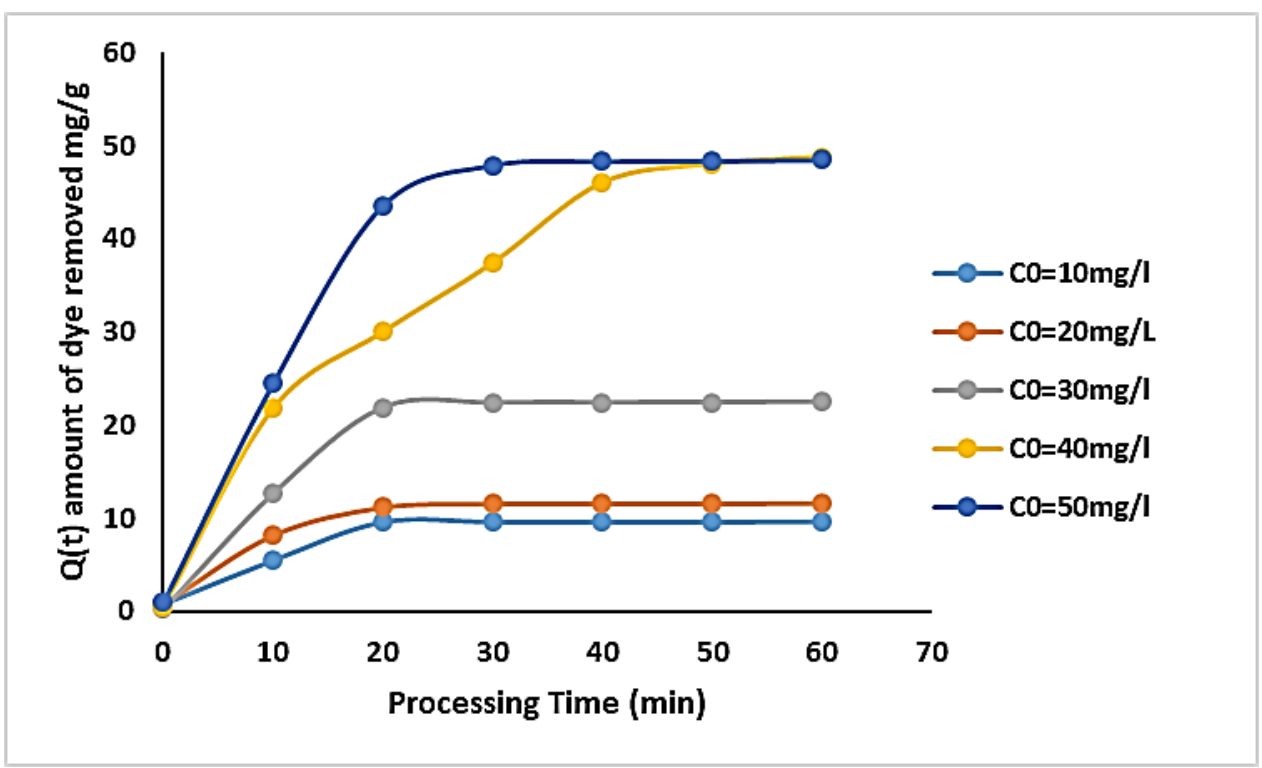

Figure 12. Effect of electrolysis time and initial concentration on the amount of reactive blue dye adsorbed (Optimal conditions) 
The adsorption model was first tested by the pseudofirst-order expressed by the Lagergren equation ${ }^{24-25}$ :

$$
\operatorname{Ln}\left(Q_{e}-Q_{t}\right)=\operatorname{Ln}\left(Q_{e}\right)-k_{1} t
$$

Where:

$\mathrm{Q}_{\mathrm{e}}$ : Amount of adsorbed dye $(\mathrm{mg})$ at equilibrium per gram of adsorbent $(\mathrm{mg} / \mathrm{g})$.

$\mathrm{k}_{1}$ : First order adsorption rate constant $\left(\mathrm{min}^{-1}\right)$.

$\mathrm{Q}_{\mathrm{e}}$ and the rate constant $\mathrm{k}_{1}$, were determined by the slope of the plots of $\operatorname{Ln}\left(\mathrm{Q}_{\mathrm{e}}-\mathrm{Q}_{\mathrm{t}}\right)$ as function of time, and intercept of the plot. The calculated $Q_{e}$ value does not agree with the experimental $\mathrm{Q}_{\mathrm{e}}$ values.

The second-order kinetic model was tested. It is expressed by the following equation ${ }^{26}$ :
$\frac{t}{Q_{t}}=\frac{1}{k_{2} Q_{e}^{2}}+\frac{1}{Q_{e}} t$

Where:

$\mathrm{k}_{2}$ : Second order adsorption rate constant (mg/g.min) The plot of $\left(\mathrm{t} / \mathrm{Q}_{\mathrm{t}}\right)$ as a function of $\mathrm{t}$ gives a straight line with the slope $\left(1 / \mathrm{Q}_{\mathrm{e}}\right)$ and intercept of the plot $\left(1 / \mathrm{k}_{2} \mathrm{Q}_{\mathrm{e}}{ }^{2}\right)^{27}$. Table 7 shows a comparison between the experimental and calculated $\mathrm{Q}_{\mathrm{e}}$ values for different dyes concentration (disperse and reactive dyes) in first and second-order kinetic models at temperature $298 \mathrm{~K}$. According to the results presented in Table 3, secondorder kinetic presents better the adsorption for all initial concentrations as the obtained equilibrium capacity is close to the experimental values of $\mathrm{Q}_{\mathrm{e}}$ and the linear regression coefficient is close to the unit.

Table 7. Results of the kinetics of pseudo-first and second order for disperse red and reactive blue dyes.

\begin{tabular}{|c|c|c|c|c|c|c|c|c|}
\hline \multirow[b]{2}{*}{ Dyes } & \multirow[b]{2}{*}{$\begin{array}{c}\text { Concentration } \\
(\mathrm{mg} / \mathrm{l})\end{array}$} & \multirow[b]{2}{*}{$\begin{array}{c}Q_{\mathrm{e}} \\
\text { "Exp." } \\
\text { (mg/g) }\end{array}$} & \multicolumn{3}{|c|}{ First order adsorption } & \multicolumn{3}{|c|}{ Second order adsorption } \\
\hline & & & $\begin{array}{c}Q_{\mathrm{e}} \\
\text { “Cal." } \\
(\mathrm{mg} / \mathrm{g})\end{array}$ & $\begin{array}{c}\mathbf{k}_{1} \\
\left(\mathbf{m i n}^{-1}\right)\end{array}$ & $\mathbf{R}^{2}$ & $\begin{array}{c}Q_{\mathrm{e}} \\
\text { "Cal." } \\
\text { (mg/g) }\end{array}$ & $\mathbf{k}_{2}(\mathrm{mg} / \mathrm{g} \cdot \mathbf{m i n})$ & $\mathbf{R}^{2}$ \\
\hline \multirow{5}{*}{$\begin{array}{l}\text { Disperse } \\
\text { Red }\end{array}$} & 10 & 9.50 & 9.28 & 0.23 & 0.8843 & 10.18 & 0.06 & 0.9973 \\
\hline & 20 & 11.51 & 23.83 & 0.41 & 0.8994 & 11.85 & 0.09 & 0.9987 \\
\hline & 30 & 22.00 & 9.09 & 0.09 & 0.6368 & 22.68 & 0.05 & 0.9986 \\
\hline & 40 & 48.00 & 59.98 & 0.08 & 0.9268 & 55.25 & 0.002 & 0.9497 \\
\hline & 50 & 48.00 & 53.97 & 0.15 & 0.9772 & 50.77 & 0.008 & 0.9929 \\
\hline \multirow{5}{*}{$\begin{array}{l}\text { Reactive } \\
\text { Blue }\end{array}$} & 10 & 9.60 & 3.18 & 0.17 & 0.7005 & 10.19 & 0.03 & 0.9842 \\
\hline & 20 & 11.24 & 32.07 & 0.47 & 0.8485 & 12.08 & 0.05 & 0.9957 \\
\hline & 30 & 22.00 & 39.06 & 0.26 & 0.8686 & 23.87 & 0.013 & 0.9839 \\
\hline & 40 & 48.00 & 58.09 & 0.07 & 0.9009 & 55.55 & 0.002 & 0.9306 \\
\hline & 50 & 47.91 & 55.33 & 0.12 & 0.9465 & 52.63 & 0.005 & 0.9746 \\
\hline
\end{tabular}

\subsection{Adsorption isotherm}

The adsorption isotherms can contribute to determining the type of adsorption allowing the determination of the maximum capacity for fixing the dyes on $\mathrm{Fe}(\mathrm{OH})_{3}$ or/and $\mathrm{Al}(\mathrm{OH})_{3}$.

In the literature, many theoretical models have been developed in order to describe the experimental data corresponding to adsorption isotherms. The Langmuir and the Freundlich models are mainly used for describing adsorption in the liquid phase.

The Langmuir model is described as follows 28,29

$\frac{1}{Q_{e}}=\frac{1}{Q_{m}}+\frac{1}{k_{L} Q_{m} C_{e}}$

The parameters $\mathrm{Q}_{\mathrm{m}}$ and $K_{L}$ will be determined by plotting the line $1 / \mathrm{Q}_{\mathrm{e}}$ versus $1 / \mathrm{C}_{\mathrm{e}_{\mathrm{e}}} \mathrm{Q}_{\mathrm{m}}$ is the maximum adsorption capacity and $K_{L}$ is related to the energy of adsorption.
The Freundlich model is described as follows:

$$
\operatorname{Ln}\left(Q_{e}\right)=\operatorname{Ln}\left(K_{f}\right)+\frac{1}{n} \operatorname{Ln}\left(C_{e}\right)
$$

Where $k_{f}$ is the Freundlich constant and $n$ is the intensity of adsorption. $K_{f}$ and $n$ are determined by plotting the curve $\operatorname{Ln}\left(\mathrm{Q}_{\mathrm{e}}\right)$ versus $\operatorname{Ln}\left(\mathrm{C}_{\mathrm{e}}\right)$.

The temperature was maintained at $25^{\circ} \mathrm{C}$ and different concentrations ranging from $10 \mathrm{mg} / \mathrm{l}$ to $50 \mathrm{mg} / \mathrm{l}$ were used. Samples were taken to determine the equilibrium concentration after $35 \mathrm{~min}$ (equilibrium time). Table 8 summarizes the results for both types of isotherms. We can notice that the experimental results of the adsorption isotherm are better represented by the Freundlich model since the correlation coefficient is close to unity. Therefore the adsorption of blue and red dyes is favored by the Freundlich isotherm based on adsorption on a heterogeneous surface. 
Table 8. Adsorption equilibrium parameters according to the Langmuir and Freundlich models.

\begin{tabular}{|c|c|c|c|}
\cline { 2 - 4 } & Parameters & Reactive Blue & Dispersed Red \\
\hline \multirow{2}{*}{ Langmuir Adsorption Isotherm } & $\mathrm{Qm}(\mathrm{mg} / \mathrm{g})$ & 454.54 & 476.2 \\
\cline { 2 - 4 } & $\mathrm{K}_{\mathrm{l}}(\mathrm{L} / \mathrm{mg})$ & 0.3142 & 0.296 \\
\cline { 2 - 4 } & $\mathrm{R}^{2}$ & 0.8065 & 0.885 \\
\hline \multirow{2}{*}{ Freundlich Adsorption Isotherm } & $\mathrm{k}_{\mathrm{f}}$ & 145.7 & 153.35 \\
\hline & $\mathrm{N}$ & 2.87 & 2.89 \\
\hline
\end{tabular}

\subsection{Thermodynamic study}

Adsorption is a phenomenon that can be endothermic or exothermic depending on the adsorbent material and the nature of the adsorbed molecules. In order to understand the thermodynamic phenomenon of the adsorption of the dyes by sacrificial anodes $\left(\mathrm{Al}(\mathrm{OH})_{3}\right.$ or/and $\left.\mathrm{Fe}(\mathrm{OH})_{3}\right)$, we carried out experiments of decolorization by varying the temperature of the synthetic effluent from 25 to $45^{\circ} \mathrm{C}$. The tests were carried out for a concentration of $40 \mathrm{ppm}$ of each type of dye (reactive blue and dispersed red) by adjusting the initial value of $\mathrm{pH}$ value between 5 and 6 and $2.5 \mathrm{mS} / \mathrm{cm}$ as conductivity by adding $2 \mathrm{~g} / \mathrm{L}$ of $\mathrm{NaCl}$.

These mixtures are kept under constant stirring for $120 \mathrm{rpm}$, duration of $60 \mathrm{~min}$. The residual concentration of the dye was determined by UV-visible spectrophotometry at the appropriate wavelength.

Thermodynamic parameters such as standard free enthalpy $\Delta \mathrm{G}^{\circ}$, standard enthalpy $\Delta \mathrm{H}^{\circ}$ and standard entropy $\Delta \mathrm{S}^{\circ}$ were determined using the following equations:

$\Delta G^{0}=-R T \times \operatorname{Ln}\left(K_{d}\right)$
The free energy $\Delta G^{\circ}$ indicates the spontaneity of a process.

The Vant'Hoff equation will allow calculating the variation of enthalpy and entropy:

$\operatorname{Ln}\left(K_{d}\right)=\frac{\Delta H^{0}}{R} \times \frac{1}{T}+\frac{\Delta S^{0}}{R}$

Where:

$K_{d}=\frac{Q_{e}}{C_{e}}: \quad$ Dye retention rate

$\mathrm{Q}_{\mathrm{e}}$ : the quantity of the dye eliminated at equilibrium; $\mathrm{C}_{\mathrm{e}}$ : the concentration at equilibrium $\left(\right.$ at $\mathrm{t}=\mathrm{t}_{\mathrm{e}}=35 \mathrm{~min}$ ) The enthalpy and entropy changes were obtained from the slope and intercept of the Van't Hoff plots of Ln $\mathrm{K}_{\mathrm{d}}$ versus $1 / \mathrm{T}$.

According to Table 9, the negative values of enthalpy obtained both for disperse red dye, and reactive blue dye indicates that the adsorption is exothermic.

The random nature of dyes adsorption is proved by the positive values of entropy. The negative values of the change of free energy indicate the adsorption is spontaneous.

Table 9. Thermodynamic parameters of the adsorption of the disperse red and reactive blue dyes on metal hydroxide $\left(\mathrm{Fe}(\mathrm{OH})_{3} / \mathrm{Al}(\mathrm{OH})_{3}\right)$.

\begin{tabular}{|c|c|c|c|c|c|}
\hline \multirow{2}{*}{ Dyes } & \multicolumn{5}{|c|}{ Thermodynamic parameters } \\
\cline { 2 - 6 } & $\mathbf{T}^{\circ} \mathbf{C}$ & $\begin{array}{c}\Delta \mathbf{S}^{\mathbf{0}} \\
(\mathbf{K J} / \mathbf{K} . \mathbf{m o l})\end{array}$ & $\begin{array}{c}\Delta \mathbf{H}^{\mathbf{0}} \\
(\mathbf{K J} / \mathbf{m o l})\end{array}$ & $\mathbf{R}^{\mathbf{2}}$ & $\begin{array}{c}\Delta \mathbf{G}^{\mathbf{0}} \\
(\mathbf{K J} / \mathbf{m o l})\end{array}$ \\
\hline \multirow{3}{*}{ Reactive blue } & 25 & 17.408 & -443.535 & 0.9996 & -5633.935 \\
\cline { 2 - 6 } & 30 & 17.408 & -443.535 & 0.9996 & -5720.978 \\
\hline & 35 & 17.408 & -443.535 & 0.9996 & -5808.021 \\
\hline \multirow{3}{*}{ Disperse Red } & 40 & 17.408 & -443.535 & 0.9996 & -5895.065 \\
\hline & 45 & 17.408 & -443.535 & 0.9996 & -5982.108 \\
\hline & 25 & 15.128 & -523.033 & 0.9898 & -5033.74 \\
\hline & 30 & 15.128 & -523.033 & 0.9898 & -5109.385 \\
\hline & 45 & 15.128 & -523.033 & 0.9898 & -5185.03 \\
\hline & 45 & 15.128 & -523.033 & 0.9898 & -5260.675 \\
\hline
\end{tabular}


To find out the energy of activation for adsorption of dyes, the second order rate constant is expressed in Arrhenius form ${ }^{25}$ :

$$
\operatorname{Lnk}_{2}=\operatorname{Lnk_{0}}-\frac{E}{R T}
$$

Where: $\mathrm{K}_{0}$ is the constant of the equation ( $\left.\mathrm{mg} / \mathrm{g} . \mathrm{min}\right)$; $E$ is the energy of activation $(\mathrm{J} / \mathrm{mol})$;

$\mathrm{R}$ is the gas constant $(8.314 \mathrm{~J} / \mathrm{mol} . \mathrm{K})$;

$\mathrm{T}$ is the temperature $(\mathrm{K})$.

The curve $\ln \mathrm{k}_{2}$ versus $1 / \mathrm{T}$ is a straight line in which the slope gives $\mathrm{E} / \mathrm{R}$ allowing the determination of the energy of activation E. For Disperse red, $\mathrm{E}=56753.03 \mathrm{~J} / \mathrm{mol}$, for reactive blue: $\mathrm{E}=41476.89 \mathrm{~J} / \mathrm{mol}$.

\subsection{Sludge analysis}

The samples were filtered immediately after the electrocoagulation was stopped using a cellulose filter of $0.2 \mu \mathrm{m}$. The brine recovered from the filter is placed in a laboratory oven at $120^{\circ} \mathrm{C}$, which is considered enough to completely dry the filtered flocs, and the recovered flocs were visualized by Scanning Electron Microscopy (SEM) using "Thermo scientific Quatro S". This study does not concern the morphology of the grains but the elementary composition of the dried flocs. Sludge samples were analyzed by EDAX coupled with SEM to quantify the elemental composition. The carbon found is only the one deposited on the sample before analysis to make the surface conductive. Sodium and chlorine are provided by the $\mathrm{NaCl}$ salt used to vary the conductivity of the solution during experience as shown in Figure 13 EDAX analysis affirms the presence of different metallic elements such as $\mathrm{Na}$ and $\mathrm{S}$, the presence of those heavy metals reflects the power of Electrocoagulation process to transfer the pollution from water to the formed sludge. As reported by Titchou et al. ${ }^{30}$

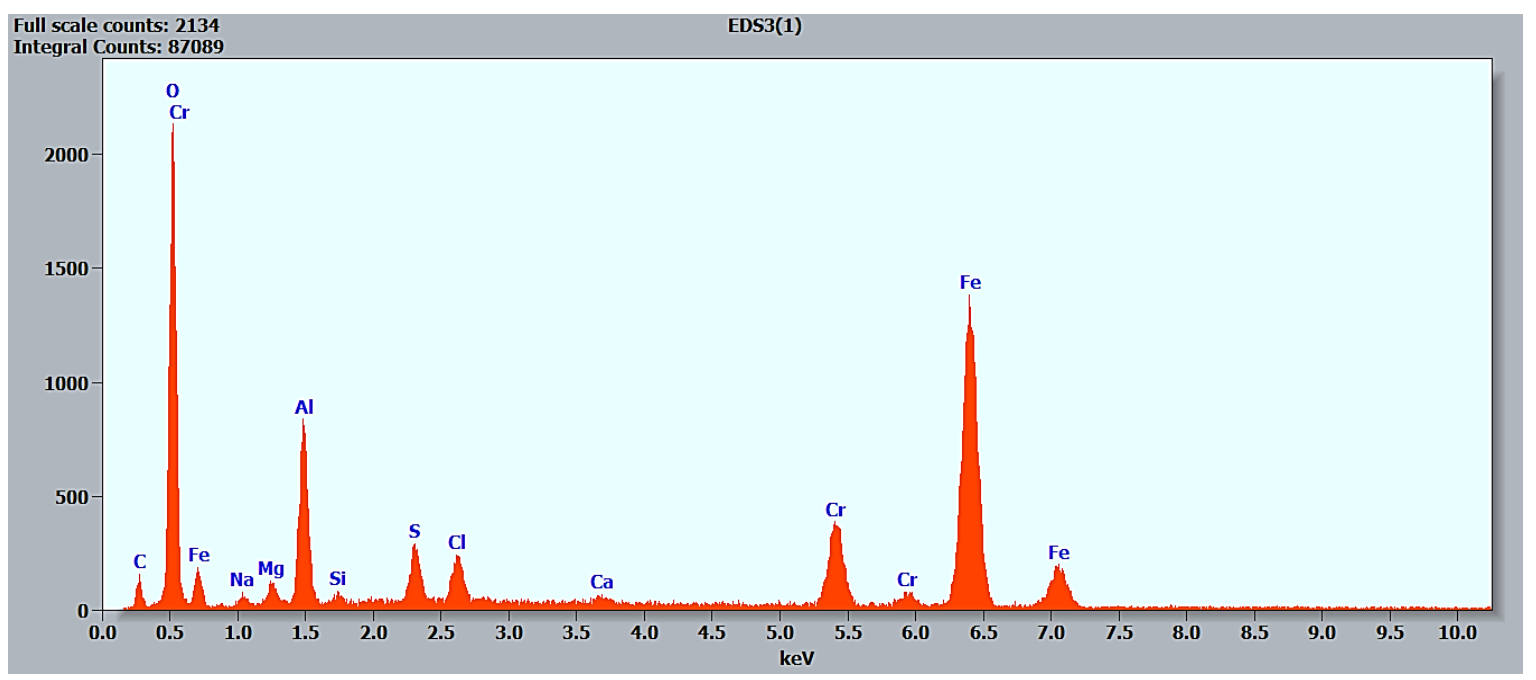

Figure 13. EDAX spectrum of the floc at $\mathrm{T}=30^{\circ} \mathrm{C}$

The floc analysis gives an amount of iron that gradually increases with temperature, which explains the loss of anode mass during the experiment. The results in Table 10 indicate that iron is more abundant than aluminum in the sludge $(40 \%$ iron, $8 \%$ aluminum) in the case of the temperature of $25^{\circ} \mathrm{C}$ and (48.7\% iron, $8.6 \%$ aluminum) in the case of the temperature of $45^{\circ} \mathrm{C}$. The amount of iron is in general seven to eight times important than aluminum.

Table 10. Elementary compositions of iron and aluminum (SEM-EDAX).

\begin{tabular}{|c|c|c|}
\hline \multirow{2}{*}{$\mathbf{T}^{\circ} \mathbf{C}$} & \multicolumn{2}{|c|}{ EDAX Analysis } \\
\cline { 2 - 3 } & Weight \%(Fe) & Weight \%(Al) \\
\hline 25 & 40.31 & 8.07 \\
\hline 30 & 40.52 & 8.50 \\
\hline 35 & 45.00 & 8.00 \\
\hline 40 & 46.00 & 8.00 \\
\hline 45 & 48.77 & 8.59 \\
\hline
\end{tabular}

The determination of the mass of the flocs as well as the consumed masses of the electrodes, especially electrochemically sacrificial anodes, can give a correlation between the results found by SEM and floc mass or mass loss of the electrodes. The floc analysis gives an amount of iron that gradually increases with 
temperature, which explains the loss of anode mass during the experiment as shown in Figure 14 and indicates that the dye removal process is by adsorption. On the other hand, it can also be noted that the mass of the floc measured depends enormously on the temperature. The influence of temperature on the mass of flocs is illustrated in the Table 11.

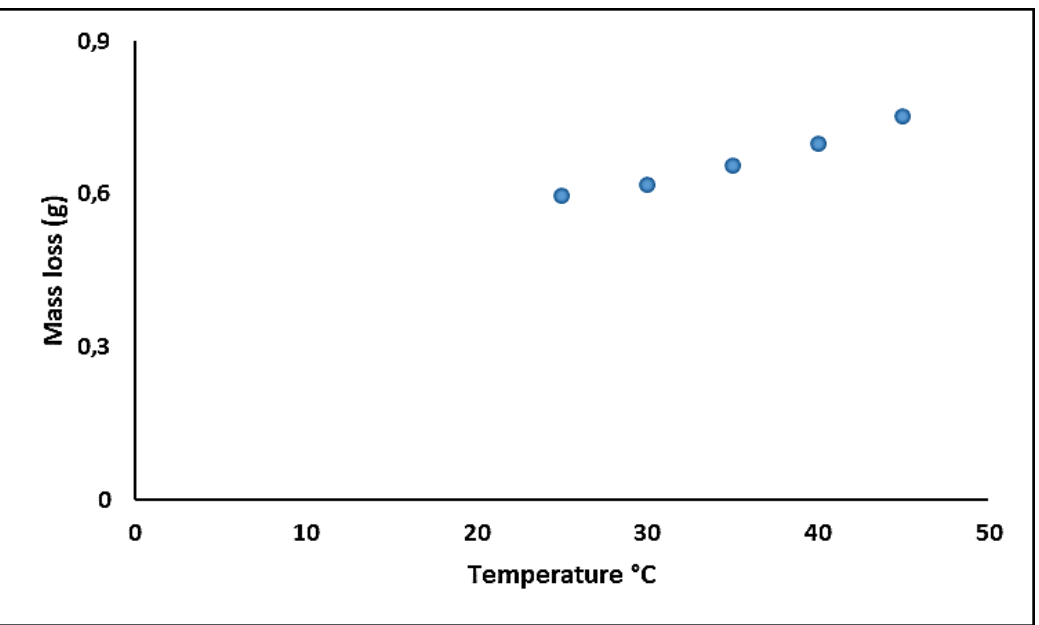

Figure 14. Effect of temperature on electrode mass loss for bipolar association (Fe-Al-Al-Fe)

Table 11. Mass of flocs generated during the experience.

\begin{tabular}{|c|c|}
\hline Temperature $\left({ }^{\circ} \mathbf{C}\right)$ & Mass of the floc $(\mathbf{g})$ \\
\hline 25 & 2.58 \\
\hline 30 & 4.84 \\
\hline 35 & 5.99 \\
\hline 40 & 6.11 \\
\hline
\end{tabular}

The extracted solution was analyzed by Inductively Coupled Plasma Spectrometry (ICP) using "Jobin Yvon Ultima 2". The quantity of iron and aluminum analyzed by ICP in each sample is given in Table 12 . The iron amount is higher than the aluminum amount and increases gradually with temperature. The obtained results show also that the treated water contains in general, the residual concentration of iron and aluminum with the amount below the standards set by national regulations in terms of heavy metals. For a temperature of $40^{\circ} \mathrm{C}$ it is above $3 \mathrm{mg} / \mathrm{l}$, which shows that high temperature causes a strong dissociation of iron, which leads to set $25^{\circ} \mathrm{C}$ as the optimal temperature.

Table 12. ICP analysis (after treatment) of synthetic effluent from the textile industry.

\begin{tabular}{|c|c|c|c|c|}
\hline \multirow{3}{*}{ Samples } & \multicolumn{4}{|c|}{ Analysis results } \\
\hline & \multicolumn{2}{|c|}{ Concentration (mg/l) } & \multicolumn{2}{|c|}{ Moroccan standards } \\
\hline & Aluminum & Iron & Aluminum & Iron \\
\hline $\mathrm{ICP}-25^{\circ} \mathrm{C}$ & 0.15 & 1.103 & \multirow{4}{*}{$10 \mathrm{mg} / 1$} & \multirow{4}{*}{$3 \mathrm{mg} / \mathrm{l}$} \\
\hline $\mathrm{ICP}-30^{\circ} \mathrm{C}$ & 0.178 & 1.265 & & \\
\hline $\mathrm{ICP}-35^{\circ} \mathrm{C}$ & 0.23 & 2.542 & & \\
\hline $\mathrm{ICP}-40^{\circ} \mathrm{C}$ & 0.188 & 3.919 & & \\
\hline
\end{tabular}

An electrochemical study will be investigated to explain the results concerning the losses of masses of the electrodes in future studies.

\section{Conclusion}

This study has shown the possibility to use combined iron and aluminum electrodes as sacrificial anodes with bipolar mode to treat mixed dyes. 
The removal of Reactive and disperse dyes from textile effluent synthetic was performed in a stirred glass tank using Electrocoagulation process. The effect of some operating conditions like the current density, initial $\mathrm{pH}$, concentration of supporting electrolyte, Processing time, and stirring speed were tested and optimized.

The objective is to carry out the best way to remove dyes with low consumption energy. The optimal conditions for $40 \mathrm{mg} / \mathrm{l}$ dyes treatment were: $20 \mathrm{~mA} / \mathrm{cm}^{2}$ of current density using Iron electrodes as sacrificial anode with $120 \mathrm{rpm}$ of stirring speed in the presence of $2.5 \mathrm{~g} / \mathrm{l}$ of $\mathrm{NaCl}, 5.9$ of initial $\mathrm{pH}$ and $60 \mathrm{~min}$ of processing time, more than $95 \%$ of color removal was achieved with consumption energy lower than $10 \mathrm{KWh} / \mathrm{Kg}$ of removed dye.

Kinetics are modeled by the pseudo-second order. The effect of temperature is essential because the amount of floc increases with temperature. The adsorption isotherm studies of mixed dyes by electrocoagulation using combined aluminum and iron electrodes is more presented by the Freundlich model.

SEM analysis and inductively coupled plasma spectrometry (ICP) have been used to quantify the role of each type of electrodes. Correlation between the mass loss of each type of electrodes and the percentage of iron and aluminum on the floc is obtained, the sludge characterization also shows the presence of different metallic elements reflecting the power of this process to transfer the pollution from water to the formed sludge.

\section{Acknowledgments}

Sincere thanks are due to Hassan II University of Casablanca for financial help and CNRST for the technical help.

\section{References}

1- J. S. Do, M. L. Chen, Decolourization of dyecontaining solutions by electrocoagulation, Journal of Applied Electrochemistry, 1994, 24, 785-790.

2- S. I. Abo-Elela, F. A. El-Gohary, H. L. Ali, R. S. Abdel-Wahaab, Treatability Studies on Textile Industry Wastewater Including High COD Loadings by Physico-Chemical, Ozone/UV and Adsorption Techniques, Environ. Technol., 1998, 9, 23-32.

3- M. Riera-Torres, C. Gutiérrez-Bouzán, M. Crespi, Combination of coagulation-flocculation and nanofiltration techniques for dye removal and water reuse in textile effluents, Desalination, 2010, 252, 53-59.

4- A. R. Khataee, V. Vatanpour, A. R. Amani Ghadim, Decolorization of C.I. Acid Blue 9 solution by UV/Nano-TiO(2), Fenton, Fentonlike, electro-Fenton and electrocoagulation processes: a comparative study, J. Hazard. Mater.,
2009, 161,1225-1233.

5- N. Mohan, N. Balasubramamian, V. Subramanian, Electrochemical Treatment of Simulated Textile Effluent, Chem. Eng. Technol., 2001, 24, 749-753.

6- M. F. Sevimli, H. Z. Sarikaya, Ozone treatment of textile effluents and dyes: effect of applied ozone dose, $\mathrm{pH}$ and dye concentration, Journal of Chemical Technology \& Biotechnology: International Research in Process, Environmental \& Clean Technolog, 2002, 77, 842-850.

7- A. M. Mamelkina, M. Herraiz-Carboné, S. Cotillas, E. Lacasa, M. A. Rodrigo, Treatment of mining wastewater polluted with cyanide by coagulation processes: A mechanistic study, Separation and Purification Technology, 2020, 237, 116345. https://doi.org/10.1016/j.seppur.2019.116345.

8- B. Al Aji, Y. Yavus, S. Koparal, Electrocoagulation of heavy metals containing model wastewater using monopolar iron electrodes, Separation and Purification Technology, 2012, 86, 248-254.

9- S. H. Ammara. N. N. Ismaila, A. D. Ali, W. M. Abbasc, Electrocoagulation technique for refinery wastewater treatment in an internal loop split-plate airlift reactor, Journal of Environmental Chemical Engineering., 2019, 7, 103489. https://doi.org/10.1016/j.jece.2019.103489.

10-W. Balla, A. H. Essadki, B. Gourich, A. Dassaa, H. Chenik, M. Azzi,

Electrocoagulation/electroflotation of reactive, disperse and mixture dyes in an external-loop airlift reactor, J. Hazard. Mater., 2010, 184, 710-716.

11-A. Hector, M. Castillas, L. David, A. Jewel, A. G. Gomes, P. Morkovsky, J. R. Parga, E. Peterson, Electrocoagulation mechanism for COD removal, Separation and purification Technology, 2007, 56, 204-211.

12-O. Ali, A. R. A. Ghadim, M. S. S. Dorraji, M. H. Rasoulifard, Removal of the alphazurine FG dye from simulated solution by electrocoagulation, CLEAN - Soil Air Water, 2010, 38, 401-408.

13-G. F. Babuna, B. Soyhan, G. Eremektar, D. Orhon, Evaluation of treatability for two textile mill effluents, Water Sci. Technol., 1999, 40, 145-152.

14-Y. M. Slokar, A. M. L. Marechal, Methods of decoloration of textile wastewaters, Dyes. Pigm., 1998, 37, 335-356.

15-H. Chenik, M. Elhafdi, A. Dassaa, A. H. Essadki, M. Azzi, Removal of Real Textile Dyes by Electrocoagulation/Electroflotation in a Pilot External-Loop Airlift Reactor, Journal of Water Resource and Protection, 2013.

16-S. Bener, Ö. Bulca, B. Palas, G. Tekin, G. Ersöz, Electrocoagulation process for the treatment of real textile wastewater: Effect of operative conditions on the organic carbon removal and 
kinetic study, Process Safety and Environmental Protection, 2019, 129, 47-54.

17-G. Jiantuan, Q. Jiuhui, L. Pengju, L. Huijuan, New bipolar electrocoagulation-electroflotation process for the treatment of laundry wastewater, Separation and Purification Technology, 2004, 36, 33-39.

18-A. H. Essadki, Electrochemical Probe for Frictional Force and Bubble Measurements in Gas-Liquid-Solid Contactors and Innovative Electrochemical Reactors for Electrocoagulation/Electroflotation, Electrochemical Cells-New Advances in Fundamental Researches and Applications. Janeza Trdine, 2012, 9, 45-70.

19-K. S. Hashim, A. H. Hussein, S. L. Zubaidi, P. Kot, L. Kraidi, R. Alkhadar, A. Shaw, R. Alwash, Effect of initial $\mathrm{pH}$ value on the removal of reactive black dye from water by electrocoagulation (EC) method, J. Phys. Conf. Ser., 2019, 1294, 072017.

20-Y. Vahap, A. Hevidar, Y. Numan, Investigation of optimum conditions for efficient COD reduction in synthetic sulfamethazine solutions by Pleurotus ernygii var. ferulae using response surface methodology, J.Taiwan. Inst. Chem. E., 2017, 80, 349-355.

21-Z. Zaroual, H. Chaair, A. H. Essadki, K. ElAss, M. Azzi, Optimizing the removal of trivalent chromium by electrocoagulation using experimental design, Chem. Eng. Journal., 2009,148, 488-495.

22-M. Bayramoglu, M. Kobya, O. T. Can, M. Sozbir, Operating cost analysis of electrocoagulation of textile dye wastewater, Sep. Purif. Technol., 2004, 37, 117-125.
23-I. Muharrem, I. O. Kaplan, Y. Vahap, Nickel, lead and Cadmium Removal Using a low-cost Adsorbent-Banana peel, At. Spectrosc., 2016, 37, 125-130.

24-S. K. Lagergren, About the theory of so-called adsorption of soluble substances, Sven. Vetenskapsakad. Handingarl, 1898, 24, 1-39.

25-V. C. Srivastava, M. M. Swamy, I. D. Mall, B. Prasad, I. M. Mishra, Equilibrium, Kinetics and Thermodynamics. Colloids and Surfaces A: Physicochemical and Engineering Aspects, Colloids and surfaces a: physicochemical and engineering aspects, 2006, 272, 89-104.

26-S. Papita Das, J. Srivastava, S. Chowdhury, Removal of phenol from aqueous solution by adsorption onto seashells: equilibrium, kinetic and thermodynamic studies, Journal of Water Reuse and Desalination, 2013, 3, 119-127.

27-Y. S. Ho, G. McKay, Pseudo-Second Order Model for Sorption Processes, Process. Biochem., 1999, 34, 451-465.

28-S. Vasudevan, J. Lakshmi, G. Sozhan, Effects of alternating and direct current in electrocoagulation process on the removal of cadmium from water, J. Hazard. Mater., 2011, 192, 26-34.

29-Y. Vahap, I. Muharem, T. Mehtap, Adsorption of bisphenol A from aqueous solutions by pleurotus eryngii immobilized on Amberlite XAD-4 using as a new adsorbent, Desalination and Water Treatment, 2016, 57, 22362-22369.

30-F. E. Titchou, H. Alfanga, H. Zazou, R. A. Akbour, M. Hamdani, Batch elimination of cationic dye from aqueous solution by electrocoagulation process, Med.J.Chem., 2020, 10, 1-12. 